\title{
Comparative analysis between public and private investment in human capital: A case of Nepal
}

\author{
Post Raj Pokharel
}

Kathmandu University School of Management, Nepal

\section{Key Words}

Human Capital, Education, Health

\begin{abstract}
Human capital investment is seen at employee's learning of job-related behavior, skills, knowledge, and attitude that tends to improve better performance. This paper compares the human capital investment in public and private sectors of Nepal using Human Capital Report, Human Development Report and Employees Opinion working at public and private enterprises. Empirical studies mostly focused human capital as a function of education and experience.

This study compares the status of human capital in the context of Nepal more specific to education and health investment. Firstly, the status of educational investment in human capital in Nepal shows significant improvement trend as primary school teachers trained percentage is increasing, pupilteacher ratio has been decreasing and the percentage of population with least some secondary education has also been increasing. Secondly, Government contribution on health expenses is at negligible level i.e. below six percent of GDP. Finally, employees' overall perception of human capital investment in private sectors has higher influence than the public sectors. This shows that government intervention on human capital investment is not adequate and found less prioritized which might be one of the key reasons for low per capita in the country.
\end{abstract}

Corresponding author: Post Raj Pokharel

Email address for corresponding author: postraj@kusom.edu.np

First submission received: 15 th November 2017

Revised submission received: $15^{\text {th }}$ March 2018

Accepted: 21 ${ }^{\text {st }}$ March 2018

\section{Introduction}

The life of the people based on their knowledge determines the identity of human capital. Recruiting people, training them, deputing for the job, appraising the performance, rewards and awards are the fundamentals for attaining job in the organizations. Retaining valuable human assets is the principal focus of human capital definition. The purpose of achieving the real performance from the people involved in the organization is considered as the human capital utilization. HCR (2013) stated human capital as it is not a one dimensional concept, but means different things to different stakeholders. In the business world, human capital is the economic value of an employee's set of skills. Understanding human capital, individuals possess varieties of human capital aspects like: knowledge, wisdom, aptitudes, skills, capabilities, understanding, intelligence, training and judgment. 
The emergence of growth concept of globalization and deregulation of national economies has put forward a lot of opportunities for the public and private houses across the world. In order to accept the opportunities and to cope with the challenges efficiently, skilled and competent human force has been considered as one of the most important factors. This is because all other things concerned with management of an organization are same, the only different is people. Only the human resource can bring the success and change in the development of an organization. Investment in human capital is the key root to achieve the sustainable economic growth of an organization. Business organizations across the world, therefore, regardless of their size and nature, have been streamlining their efforts and resources to develop skilled and competent work force providing them continuous coaching, training and other career development opportunities. They are trying to make their workforce better and different from others. More specifically, they are empowering their workforce for high performance and better results. Developing and strengthening of human capital is, therefore, essential to ensure the long-term success in today's dynamic business environment.

The expected rate of human capital return based on the performance and its standardization is the key issue in public and private houses for developing and undeveloped countries. The organizations are primarily focused on human based keeping large number of people at all levels. Treating people as human capital is only possible, once the expected level of output is obtained.

Human capital is the financial value that an employee provides to an employer. The valuation of this value is related to the body of skill, knowledge, and experience that the employee possesses. The prominent factor creating human capital in the organization such as formal education and participation in ongoing training related to the workplace.

As one of the basic factors of production, human capital is essential to the operation of just about any type of business. Employing individuals who have the necessary knowledge, talents and ability to function within their assigned roles allows the business to operate at maximum efficiency. This in turn increases the potential of earning a profit, and remaining successful for many years. A failure to identify individuals with the necessary combination of skills, experience, and education can undermine the efforts of even the well-organized company.

In order to capture of the value of human capital, businesses often make human capital investments. The establishment of exclusive human resource department for the purpose of maintaining talent human resource in the organization is not professionally practiced. The investment in new technology that enhances its internal communication processes, the business can identify employees who demonstrate an aptitude for needed skills and arrange for those employees to receive professional instruction. This allows the company to have access to a wider skill set without the need to hire additional people. At the same time, the business helps to raise the economic value of each of those employees.

Many researchers and economists have focused Human capital with economics mainly on education, which increases the skill level of the work force in addition to its ability to adapt to new technology. Schultz (1994) focused Human capital investment separating to men and women in order to assess the private and social rates of return to human capital investments in women and men. He examines relative investments in the education, health, and nutrition of women and men, as well as the effects of traditional social roles of men and women. He tried to present the trends in education and health, and changes in the role of women profoundly affect not only women's earning power in relation to that of men, but also their mortality and fertility. Schultz (1994) in his paper also stat- 
ed that South Asia exhibit large differences in the education of men and women and in this region the gender gap is only closing slowly.

In the context of Nepal, importance of human capital was overlooked in public and private institutions. The sense of retaining right type of people in the organizations has been keenly felt. The rise of technological advancement, digital information through online media and social network like Facebook and twitter has changed the traditional concept into behavioral need and also values of the workforce and increasing domestic as well as global competition have created enormous pressure on organizations to change not only what they do but how they do it as well. Consequently, the investment on human capital has gained increasing importance in overall management of the organization regardless of their size and nature, whether they are profit or non-profit making, public or private. Now, human capital management has occupied a central position in organizational management. But still the development aspect of human capital has not received as much attention as it deserves. The financing on human capital is a planned effort to facilitate.

Employee's learning of job-related behavior, skills, knowledge, and attitude in order to improve employee performance. It is a continuous process basically designed to enhance employee's performance and satisfaction thereby improving organizational efficiency and effectiveness. In the present context of competitive and dynamic business environment

Highlighting the importance of people in organization Khera (1999) opined that today when most business houses are obsessed with Total Quality Management (TQM) in order to stay ahead of competition, very few organizations realize that their most precious assets are their employees. It is Total Quality People (TQP) that holds the key to a successful enterprise. Khera further states:

Both the American Society of Training and Development and Motorola have found that for every dollar invested by a corporation in human resource development, they received a thirty-dollar return on their investment. Training people did not cost the company much but not training them cost twenty-nine dollars.

Nepalese business organizations are no longer untouched and uninfluenced from global trend of increasing competition, rapid change in technology and demand for competent and multiskilled workforce. Consequently, they are experiencing a stiff domestic as well as external competition with rising demand for trained and skilled manpower. Analyzing the Nepalese context, Agrawal (1999) observes that human resource development has remained an area of least priority in Nepalese organizations. Training is not regarded as an investment in human resources. If there is a budget cut, training becomes the first victim. Likewise, Adhikari (1992) opined that training for the workers tend to be the area of the least consideration. Some of the factory managers viewed training is not necessary

At the lower level, employees learn by doing. Most of the workers are self-trained. In some organizations there are provisions for on-the-job training, but it is irregular. In the above context, what practices Nepalese organizations have been pursuing to develop their human capital to keep them ready to work in changing environment and work standard is a subject of interest for investigation. An attempt, therefore, has been made here to study the trend of financing on human capital in business organizations of Nepal.

\section{ii. Review of empirical works}

Lewis (1954) put forward in the field of Economic Development and consequently the idea of human capital "Economic Development with Unlimited Supplies of Labour." The term "human capi- 
tal" was not used due to its negative undertones until it was first discussed by Arthur Cecil Pigou: "There is such a thing as investment in human capital as well as investment in material capital. So soon as this is recognized, the distinction between economy in consumption and economy in investment becomes blurred. For, up to a point, consumption is investment in personal productive capacity. This is especially important in connection with children: to reduce unduly expenditure on their consumption may greatly lower their efficiency in after-life. Even for adults, after we have descended a certain distance along the scale of wealth, so that we are beyond the region of luxuries and "unnecessary" comforts, a check to personal consumption is also a check to investment.

Schultz (1994) contributed to the development of the subject matter. The best-known application of the idea of "human capital" in economics is that of Becker (1993) stating human capital similar to "physical means of production", e.g., factories and machines: one can invest in human capital (via education, training, medical treatment) and one's outputs depend partly on the rate of return on the human capital one owns. Thus, human capital is a means of production, into which additional investment yields additional output. Human capital is substitutable, but not transferable like land, labor, or fixed capital.

Flippo (1984) stating human resource management theories, suggested a close correlation between availability of development opportunities in an organization and performance of the people working with it. Development has to do with the increase of skill, through training, that is necessary for proper job performance. Development consists of training to increase skills and knowledge to do a particular job, and education that is concerned with increasing general knowledge, understanding, and background. There are two broad groups of individuals to be trained- operatives and managers.

Human Capital Report (2013) put forward the concept; human capital is the capacity of the population to drive economic growth. Traditionally, human capital has been viewed as a function of education and experience, the latter reflecting both training and learning by doing. But in recent years, health (including physical capacities, cognitive function and mental health) has come to be seen as a fundamental component of human capital. The Index is thus based on four pillars: three core determinants of human capital (education, health and employment) plus those factors that allow these three core determinants to translate into greater returns.

DeCENZO and Robbins (1996) opine that employee training has become increasingly important as job have become more sophisticated and influenced by technological changes. They classified the formal employee training methods into on-the-job training and off-the-job training. Concerning the management development training, they further state:

Management development is more future oriented and concerned with education, than is employee training, or assisting a person to become a better performer. By education, we mean that management development activities attempt to instill sound reasoning process-to interpret knowledge-rather than teaching a specific set of motor skills. Development, therefore, focuses more on employee's personnel growth.

Decenzo and Robbins (1996) stated with relevant to human capital essentials that on-the-job management development technique includes coaching, understudy assignment, job rotation, and committee assignment; and off-the-job management development technique includes sensitivity training, transactional analysis, lecture course, simulation exercise.

Bernardin and Russel (1993) opine that over the years, training has become increasingly popular as human resource tool for improving employee and managerial performance in organization. It 
has been estimated that majority of organizations provide some type of formal training and spend millions of dollars doing so. They further write:

While top managers recognize the value of training to help their firms gain a competitive edge, so too do employees. Employees understand that opportunities for training enable them to grow and advance in their careers. Companies are offering a variety of training programs to meet their organizational need.

Referring to the future challenges of organization, Bernardin and Russel (1993) made an observation that increased competition; rapid changes in technology, the growing diversity of the workforce and occupational obsolescence are among the most important challenges for the next decade. Training is one of the most important responses to these challenges. In addition to training, employee empowerment is equally important for better performance and better results.

Recently, IMF (2017) reported on the issue relating to the macroeconomic effects of public investment with specific focus on spending on schools not higher in developing economies and the determinants of the composition of public infrastructure investment. The result showed that some governments' apparent failure to invest more in schools. IMF (201) also reported that political myopia also has key role on determining investment in public composition.

It is evident from the above discussion that providing development opportunities to the employees and empowering them in the organization are the vital aspects of building human capital as they improve not only individual and organizational performance but also keep the organization ready to cope with emerging challenges.

\section{Sources of data and nature of study}

At the outset, the management philosophies and some approaches towards people including related past studies were reviewed. Being a descriptive study, survey research design was applied to collect required data through the help of published Human Development Report, online information and responses from employees working in public and private enterprises. Eleven Masters of Business Administration (MBA) students were used to collect the information from four key cities of Nepal (i.e. Kathmandu, Chitwan, Birgunj and Pokhara). Structured interviews were administered to the employees of public organizations and top level managers and working employees of private houses. This paper incorporates only ranking human capital investment information has been presented.

\section{Empirical analysis}

\section{Human Capital Investment}

Schultz (1994) stated that educational investment is the first major category of human capital accumulation. Education provides private return to the individuals along with organizational and social returns to the society. Private and social returns of education generally appear to be higher in low income generating countries like: Nepal where anticipated per capita income shall be achieved if the growth in educational investments be made.

\section{Education}

Under education investment, regardless of investment budget in education, developing countries like: Nepal, average years of schooling, percentage of primary school teachers trained to teach, number of pupil per teacher, percentage of population with least some secondary education signify the extend of educational investment. 
Table 1: Status of educational investment in human capital

Panel A: Yearly percentage of primary school teachers trained to teach from 2000 to 2015

\begin{tabular}{l|c|c|c|c|c|c|c|c}
\hline Year & 2000 & 2005 & 2010 & 2011 & 2012 & 2013 & 2014 & 2015 \\
\hline Primary school teachers trained to teach (\%) & 31 & 74 & 81 & 93 & 92 & 94 & 94 & 95 \\
\hline
\end{tabular}

Panel B: Yearly pupil-teacher ratio i.e. number of pupil per teacher from 1990 to 2015

\begin{tabular}{|l|c|c|c|c|c|c|c|c|c|c}
\hline Year & 1990 & 1995 & 2000 & 2005 & 2010 & 2011 & 2012 & 2013 & 2014 & 2015 \\
\hline $\begin{array}{l}\text { Pupil-teacher ratio, primary school (number } \\
\text { of pupils per teacher) }\end{array}$ & 39 & 39 & 38 & 40 & 32 & 30 & 28 & 26 & 24 & 23 \\
\hline
\end{tabular}

Panel C: Percentage of population with at least some secondary education ages $\mathbf{2 5}$ and above

\begin{tabular}{|r|c|c|c|c|c|c|c|c|c|c|}
\hline Year & 1990 & 1995 & 2000 & 2005 & 2010 & 2011 & 2012 & 2013 & 2014 & 2015 \\
\hline $\begin{array}{l}\text { Population with at least some secondary } \\
\text { education (\% ages 25 and older) }\end{array}$ & 17.3 & 18.3 & 19.2 & 23.2 & 27.4 & 28.5 & 29.7 & 30.9 & 32 & 32 \\
\hline
\end{tabular}

Source: Collection from Human Development Report

The status of educational investment in human capital in Nepal shows significant improvement trend as primary school teachers trained percentage is increasing, pupil-teacher ratio has been decreased to 23 (in 2015) from 39 (in 1990) and the percentage of population with least some secondary education has been increased to 32. Since the improvement in educational investment from the government sectors have been noticed but the significant improvements have not yet been achieved.

In the context of Nepalese public sectors, human capital investment is mainly observed through the official training program conducted by Nepal Administrative Staff College (NASC) as per the Nepal Administrative Staff College Act, 1982. NASC is responsible for providing necessary trainings for the employees of the Government of Nepal and public enterprises. Entire capacity enhancement program throughout the country is the launched by NASC based on the specific policies that incorporates the skill development at all levels of employees of the public enterprises.

Table 2: Nepal's Education Index

\begin{tabular}{c|c|c|c|c|c|c|c|c|c|c}
\hline Year & 1990 & 1995 & 2000 & 2005 & 2010 & 2011 & 2012 & 2013 & 2014 & 2015 \\
\hline Education Index & 0.276 & 0.299 & 0.33 & 0.359 & 0.443 & 0.458 & 0.466 & 0.474 & 0.475 & 0.475 \\
\hline
\end{tabular}

\section{Health}

How does illness discourage the development in human capital and also the income of the people like Nepal is the great concern as Nepalese health finds itself human capital and also input to producing other forms of human capital? It is said that poor country tend to be unhealthy and unhealthy countries tend to be poor and obviously its natural because health is the ability to create income so it is a kind of human capital. As opined by Schultz (1994), health investments are the second major category of human capital accumulation. The allocation of fund for health in Nepal seemed at the lower level and its contribution to GDP is still below 6\%. 
Table 3: Percentage of Health Expenditure on GDP

Panel A: Nepal - Health Expenditure - Total health expenditure (\% of GDP)

\begin{tabular}{c|c|c}
\hline Date & Value(\% of GDP) & Change, $\%$ \\
\hline 2014 & 5.8 & $1.95 \%$ \\
\hline 2013 & 5.7 & $-3.50 \%$ \\
\hline 2012 & 5.9 & $-12.43 \%$ \\
\hline 2011 & 6.7 & $4.63 \%$ \\
\hline 2010 & 6.4 & $0.37 \%$ \\
\hline 2009 & 6.4 & $-0.44 \%$ \\
\hline 2008 & 6.4 & $10.18 \%$ \\
\hline 2006 & 5.8 & $2.53 \%$ \\
\hline 2005 & 5.7 & $-0.48 \%$ \\
\hline 2004 & 5.7 & $-1.70 \%$ \\
\hline 2003 & 5.8 & $6.17 \%$ \\
\hline
\end{tabular}

Panel B: Health expenditure on both the public and private

\begin{tabular}{c|c|c|c|c}
\hline \multirow{2}{*}{ Date } & \multicolumn{2}{|c|}{ Public } & \multicolumn{2}{|c}{ Private } \\
\cline { 2 - 5 } & PPP \$ Per Capita & Change, $\%$ & PPP \$ Per Capita & Change, $\%$ \\
\hline 2014 & 40.3 & $3.30 \%$ & 59.7 & $-2.11 \%$ \\
\hline 2013 & 39 & $-6.74 \%$ & 61 & $4.86 \%$ \\
\hline 2012 & 41.9 & $-13.11 \%$ & 58.1 & $12.19 \%$ \\
\hline 2011 & 48.2 & $8.07 \%$ & 51.8 & $-6.49 \%$ \\
\hline 2010 & 44.6 & $1.15 \%$ & 55.4 & $-0.91 \%$ \\
\hline 2009 & 44.1 & $4.08 \%$ & 55.9 & $-2.99 \%$ \\
\hline 2008 & 42.4 & $8.35 \%$ & 57.6 & $-5.36 \%$ \\
\hline 2007 & 39.1 & $8.89 \%$ & 60.9 & $-4.98 \%$ \\
\hline 2006 & 35.9 & $29.61 \%$ & 64.1 & $-11.34 \%$ \\
\hline 2005 & 27.7 & $1.41 \%$ & 72.3 & $-0.53 \%$ \\
\hline 2004 & 27.3 & $-1.95 \%$ & 72.7 & $0.75 \%$ \\
\hline 2003 & 27.9 & & 72.1 & \\
\hline$S 0 u r c e$
\end{tabular}

Source: https://knoema.com/atlas/Nepal/topics/Health/Health-Expenditure/General-government-expenditureon-health-percent-of-THE

Public health expenditure consists of recurrent and capital spending from government (central and local) budgets, external borrowings and grants (including donations from international agencies and nongovernmental organizations), and social (or compulsory) health insurance funds. It covers the provision of health services (preventive and curative), family planning activities, nutrition activities, and emergency aid designated for health but does not include provision of water and sanitation. While comparing public and private, per capita expenditure of private seemed higher in the 
context of Nepal that shows that government contribution to the human capital development is not adequate.

In the context of Nepal, Human Development Report (2016) stated on the subject human development approach and 2030 agenda has made 17 sustainable goals, out of which goal no. 4 "Ensure inclusive and equitable quality education and promote lifelong learning opportunities for all" which is quite relevance and integrated with human capital investment.

Table 4: Human Capital Index:

Showing overall and age-wise HCI score and their respective ranking position of Nepal in the world based on the Human Capital Report 2016.

\begin{tabular}{l|l|l}
\hline Human Capital Index & Score & Rank/130 \\
\hline Overall & 57.35 & 108 \\
\hline Under 15 age group & 74.56 & 95 \\
\hline 15 - 24 age group & 62.11 & 84 \\
\hline 25 - 54 age group & 52.51 & 110 \\
\hline 55 - 64 age group & 44.53 & 124 \\
\hline 65 and Over age group & 30.86 & 123 \\
\hline
\end{tabular}

Source: The Human Capital Report (2016)

Nepal has been ranked as 108 in the world in Human capital index that has been released today by the World Economic Forum. The Human Capital Index quantifies how countries are developing and deploying their human capital, and tracks progress over time. It evaluates the levels of education, skills and employment available to people in five distinct age groups. In the 0-14 age group Nepal ranks $95^{\text {th }}$, in the $15-24$ age group it ranks $84^{\text {th }}$, in the $25-54$ age group it ranks $110^{\text {th }}$, in the 5564 age group it ranks $124^{\text {th }}$ and in the $65+$ category it ranks $123^{\text {rdamong }}$ the world nations.

The overall Human Development Index and its ranking of Nepal show the standing position in this global arena. HDI measures the overall extent of human capital investment presenting academic, health and income level.

Table 5: Key Indicators of Human Capital under Education

\begin{tabular}{c|c|c|c|c|c|c}
\hline Year & HDI & $\begin{array}{c}\text { Life expectancy at } \\
\text { Birth (Years) }\end{array}$ & $\begin{array}{c}\text { Expected years } \\
\text { of schooling }\end{array}$ & $\begin{array}{c}\text { Mean years } \\
\text { of schooling }\end{array}$ & $\begin{array}{c}\text { Gross national income } \\
\text { (GNI) per capita }\end{array}$ & $\begin{array}{c}\text { HDI } \\
\text { Rank }\end{array}$ \\
\hline 2015 & 0.558 & 70 & 12.2 & 4.1 & 2,337 & 144 \\
\hline
\end{tabular}

Source: Human Development Report, 2016

Remarks: The center for Human Development and Innovation is established as an independent organization dedicated to investigating complex human development challenges facing Nepal. The center has taken objectives to mainly focus in relevant to human capital is primarily knowledge management and professional development.

\section{Nepal's Human Capital Investment specific to Private Sectors}

In the context of Nepal, private sectors have considered the human capital investment as employees' development. The common types of human capital investment in private sectors in Nepal are through education and training. Primarily, technical education is focused on skill development in the areas like: production, accounting and engineering sectors. Both on the job and off the job train- 
ings have been in practice. Supervisors are made responsible on providing on-the-job training regarding the completion of deputed function as per the procedures. More interestingly, top level skilled people gave low attention on availing on-the-job training to their subordinates. They are more prone to provide off-the-job. Attitudinal based trainings have been more focused the current moment. The reason behind is the migration of skill and educated employee to foreign countries. Through training which they assume to increase the overall efficiency and reduce the wasted resources from unskilled type of human resource. Professional based private companies often calculate the education and training benefits with real output using a cost-benefit analysis and compare between the expected output and actual output which the private organizations referred as return on human capital investment. The positive return on investment of human capital gives additional budget for the forthcoming years to launch human capital developmental programs.

\section{Employee Opinion on Human Capital Investment}

Table 6: Ranking Scores on Public and Private Investment of Human Capital in Nepal

This table presents the observed responses on ranking scores of the variables relevant to human capital investment in Nepal as perceived by the employees of public and private organizations. The rank order 1 indicates the least investment, 2 indicated little investment, 3 indicate average, 4 indicates more investment and 5 indicating the most investment in human capital variables. Also reported are the weighted mean value of ranking scores, standard deviations, and overall ranks.

\begin{tabular}{|c|c|c|c|c|c|c|c|c|c|c|c|c|}
\hline \multirow{2}{*}{ Human Capital Variables } & \multicolumn{6}{|c|}{ Ranking of Public Sectors } & \multicolumn{6}{|c|}{ Ranking of Private Sectors } \\
\hline & 1 & 2 & 3 & 4 & 5 & Average & 1 & 2 & 3 & 4 & 5 & Average \\
\hline $\begin{array}{l}\text { Employee Training and } \\
\text { Development }\end{array}$ & 5 & 36 & 78 & 64 & 26 & 3.3317 & 6 & 20 & 59 & 58 & 66 & 3.7596 \\
\hline $\begin{array}{l}\text { Health care support and } \\
\text { treatment }\end{array}$ & 7 & 9 & 53 & 88 & 52 & 3.8077 & 8 & 16 & 47 & 72 & 66 & 3.8221 \\
\hline $\begin{array}{l}\text { Study facilities, Study } \\
\text { leave and scholarships }\end{array}$ & 0 & 18 & 100 & 89 & 2 & 3.3606 & 4 & 17 & 32 & 81 & 75 & 3.9856 \\
\hline $\begin{array}{l}\text { Exposure, fieldtrips, semi- } \\
\text { nar and conferences }\end{array}$ & 68 & 74 & 67 & 0 & 0 & 2.00 & 9 & 14 & 47 & 65 & 74 & 3.8654 \\
\hline
\end{tabular}

\section{Source: Employees survey}

Qualitative information obtained through employees has been made to justify the quantitative results. The employees who are familiar to the concept of human capital investment made attempt to provide their opinion as per their experience and feeling in the mind. The survey result showed that human capital investment in private sectors has higher influence than the public sectors. Current position of human capital investment in the areas of training, education and health care facilities are above the average but the least investment has been observed in the areas of exposure, fieldtrips, seminar and conferences from the public sectors which are the discouraging part in comparison to the private sector in Nepal.

\section{Conclusions}

The major conclusion of the paper is that human capital investment in Nepal is not sufficient enough to justify the expected level of output. Employees' perception on human capital investment is at the moderate level and needs to inject investment. 
Policy Recommendation from Asian Development Bank: Nepal must ramp up investment in human capital development so as to churn out quality human resources required for sustained economic development of the country.

\section{Research limitations and directions for further research}

This study is primarily based on international published report and opinion survey among the selected public and private institutions. Because of the data availability and access only education and health related issued were made consideration on incorporating the human capital investment, where as two key issues i.e. training and exposure were added under opinion based survey. The study suggests incorporating further relevant variables that have strong impact on human capital investment in further studies. The study also suggests using robust methodological issues like: use of human capital model that reflects the sensitivity of the variables under human capital investment.

\section{References}

Adhikari, D.R. (1992). Human Resource Management for Public Enterprise: A Model for Designing Jobs in Nepalese Factories. Badan-Badan: Nomos Verlangsgesellschaft.

Agrawal, G.R. (1999). Organization and Management in Nepal. M.K. Publisher and Distributor, Kathmandu

Becker G. (1993) (1964). Human capital: a theoretical and empirical analysis, with special reference to education. Chicago: The University of Chicago Press (3rd ed.).

Bernardin, H.J., and Russel J.E. A. (1993). Human Resource Management: An Experiential Approach. Singapore: McGraw-Hill, Inc.

DeCENZO, D.A., and S.P. Robbins. (1996). Personnel/Human Resource Management. New Delhi: Prentice-Hall of India Pvt. Ltd., 3rd ed.

Flippo, E.B. (1984). Personnel Management. Singapore: McGraw-Hill, Inc., 6th ed. Human Capital Report (2013).

IMF (2017). Investing in Public Infrastructure: Roads or Schools ?, WP/17/105

Khera, S. (1999). Just How Important Is It?Business Age 1:36.

Lewis W.A. (1954). Economic Development with Unlimited Supplies of Labour.

Nepal Human Development Report (2016)

Schultz T. P. (1994). Human Capital Investment in Women and Men Micro and Macro Evidence of Economic Returns. An International Center for Economic Growth Publication. San Francisco, California 